\title{
Purification of human alpha uterine protein
}

\author{
R. G. Sutcliffe, A. E. Bolton*, F. Sharp†, L. V. B. Nicholson and \\ R. MacKinnon
}

The Institute of Genetics, Glasgow University, Church Street, Glasgow G11 5JS; *Department of Pathology, Bolton Royal Infirmary, Bolton, Lancashire BL1 4QS; and †University Department of Midwifery, Queen Mother's Hospital, Yorkhill, Glasgow G3 8SJ, U.K.

\begin{abstract}
Summary. Human alpha uterine protein (AUP) has been prepared from extracts of decidua by antibody affinity chromatography, DEAE Sepharose chromatography and by filtration through Sephadex G-150. This procedure yielded a protein fraction containing AUP, which was labelled with ${ }^{125} \mathrm{I}$ by chloramine $\mathrm{T}$. When analysed by SDS gel electrophoresis this radioiodinated protein fraction was found to contain predominantly a single species of protein which was precipitated by antibodies against AUP in antibody-antigen crossed electrophoresis. Rabbit anti-AUP precipitated $55-65 \%$ of the tracer in a double-antibody system. Sephadex G150 gel filtration of AUP obtained before and after affinity chromatography provided a molecular weight estimate of 50000 . Since SDS gel electrophoresis revealed a polypeptide molecular weight of $23000-25000$, it is suggested that AUP is a dimer.
\end{abstract}

\section{Introduction}

Serological studies by Sutcliffe, Brock, Nicholson \& Dunn (1978) revealed a protein in human amniotic fluid which is also detectable in the uterus of pregnant women. This protein, designated $\alpha_{2}$-uterine protein (AUP), appears to be a tissue-specific protein within the sensitivity limits of antibody-antigen crossed electrophoresis (AACE) methods because it cannot be detected in saline extracts of normal human male tissues. This raises the possibility that AUP may serve as a specific protein marker in the study of uterine dysfunction and its diagnosis, provided that it can be readily assayed in fluids such as serum, uterine fluid or cervical mucus. However, AUP is not detectable by AACE in the serum of the mother or of non-pregnant women and a sensitive radioimmunoassay is therefore needed before the clinical significance of the protein can be determined and its tissue specificity characterized. The present paper describes the purification and subunit structure of AUP.

\section{Materials and Methods}

Anti-AUP Sepharose. Rabbit anti-AUP was raised by injecting rabbits with a tissue-protein fraction obtained from second trimester human amniotic fluid (see Sutcliffe et al., 1978). After solution adsorption of this antiserum with serum from adult men, rabbit immunoglobulin was precipitated from $20 \mathrm{ml}$ serum by the addition of neutral $\left(\mathrm{NH}_{4}\right)_{2} \mathrm{SO}_{4}$ to a final saturation of $40 \%$. The precipitated protein was twice washed with $\left(\mathrm{NH}_{4}\right)_{2} \mathrm{SO}_{4}$ solution at the same concentration, before being resuspended in $0.1 \mathrm{M}-\mathrm{NaHCO}_{3}$ and dialysed against 100 volumes of the same medium for $20 \mathrm{~h}$ at $4^{\circ} \mathrm{C}$. The protein was then coupled to Sepharose (Pharmacia) by the $\mathrm{CNBr}$ method of Porath, Axén \& Ernback (1967) as described by Sutcliffe et al. (1978). 
Affinity chromatography. AUP was purified from an aqueous extract of uterine decidua by antibody affinity chromatography, followed by ion-exchange chromatography and gel filtration. A specimen of human decidua ( $710 \mathrm{mg}$ wet weight) was obtained from a termination of pregnancy by hysterotomy at 11 weeks of gestation, was homogenized in 2 volumes of phosphate-buffered saline (PBS: $0.16 \mathrm{M}-\mathrm{NaCl}+5 \mathrm{~mm}$-potassium phosphate, $\mathrm{pH} 7.5$ ) and was centrifuged at $15000 \mathrm{~g}$ for $20 \mathrm{~min}$. This yielded a final soluble protein concentration of 14.6 $\mathrm{mg} / \mathrm{ml}$. An aliquot $(0.2 \mathrm{ml})$ was applied to the immunosorbent column and was washed through in PBS at $40 \mathrm{ml} / \mathrm{h}$ at $4^{\circ} \mathrm{C}$. The protein which emerged from the column was monitored spectrophotometrically at $280 \mathrm{~nm}$ and washing was continued until the absorbance fell to background levels. Protein which was still bound to the immunosorbent was eluted by washing with $2.0 \mathrm{M}-$ $\mathrm{KI}, 50 \mathrm{~mm}$-Tris $(\mathrm{pH} 8.0)$ for $1 \mathrm{~h}$ at a flow rate of $120 \mathrm{ml} / \mathrm{h}$ at $4^{\circ} \mathrm{C}$. This procedure was repeated 14 times and the eluted material was stored at $-20^{\circ} \mathrm{C}$ before being pooled into a final volume of 1.681 and being dialysed against two changes, each of 51 of $10 \mathrm{~mm}$-potassium phosphate, 50 $\mathrm{mm}-\mathrm{NaCl}(\mathrm{pH} \mathrm{7.5)}$ for $24 \mathrm{~h}$, and then against three changes, each of $5 \mathrm{l}$, of $10 \mathrm{~mm}$-potassium phosphate $(\mathrm{pH} 7 \cdot 5)$ for $36 \mathrm{~h}$, at $4^{\circ} \mathrm{C}$.

DEAE Sepharose chromatography and gel filtration. A $2.5 \times 20 \mathrm{~cm}$ column of DEAE Sepharose (Pharmacia) was equilibrated with $10 \mathrm{~mm}$-potassium phosphate $(\mathrm{pH} 7.8)$ at $4^{\circ} \mathrm{C}$. The dialysed material which had been dissociated from the immunosorbent column was passed through the ion-exchange column at $68 \mathrm{ml} / \mathrm{h}$ and the unadsorbed protein was washed through in the same buffer. When the absorbance at $280 \mathrm{~nm}$ was at background level, a linear gradient was Opplied to the column at $30 \mathrm{ml} / \mathrm{h}$, starting with $500 \mathrm{ml} 10 \mathrm{~mm}$-potassium phosphate $(\mathrm{pH} \mathrm{7.8)}$, and ending with $500 \mathrm{ml} 10 \mathrm{~mm}$-potassium phosphate, $0.2 \mathrm{M}-\mathrm{NaCl}(\mathrm{pH} \mathrm{6.5)}$. Fractions were collected $(12 / \mathrm{h})$ and tested for AUP and albumin by one-dimensional AACE. Fractions containing most of the AUP were pooled $(107 \mathrm{ml})$ and concentrated by ultrafiltration at $4{ }^{\circ} \mathrm{C}$ to a final volume of $4.5 \mathrm{ml}$ using an Amicon PM 10 membrane (exclusion: 10000 ). This material was concentrated 2-fold by freeze-drying and was applied with $0.3 \mathrm{mg}$ blue dextran to a $0.9 \times$ $48 \mathrm{~cm}$ column of G-150 Sephadex which had previously been equilibrated in PBS. Gel filtration was carried out with $5.6 \mathrm{ml} \mathrm{PBS} / \mathrm{h}$ and $1.0 \mathrm{ml}$ fractions were collected and assayed for AUP by one-dimensional AACE.

The calibration of the G-150 Sephadex column for molecular weight was carried out with pure proteins (Sigma Chemical Company). The proteins were: equine myoglobin (mol. wt = 17000 ); bovine $\alpha$-chymotrypsinogen-A (25 666); hog pepsin (35 000); bovine $\beta$-lactoglobulin (36 800); hen ovalbumin (43000); haemoglobin A (61986); and bovine serum albumin (68 000).

After gel-filtration of AUP the fraction containing the maximum concentration of AUP was freeze-dried, re-suspended in $60 \mu \mathrm{l} \mathrm{PBS}$ and a $10 \mu \mathrm{l}$ aliquot was radioiodinated with ${ }^{125} \mathrm{I}$ by the method of Hunter \& Greenwood (1962). After the iodination reaction, labelled protein was separated from unreacted radioiodide on a $0.9 \times 10 \mathrm{~cm}$ Sephadex G-25 column.

Polyacrylamide gel electrophoresis. High $\mathrm{pH}$, discontinuous $10 \%$ polyacrylamide tube gels $(\mathrm{pH} 8.9)$ were run using the method of Maizel (1971). SDS-polyacrylamide slab gels $(16 \times 19$ $\mathrm{cm}$ ) were run according to the method of Marsden, Crombie \& Subak-Sharpe (1976) but using a uniform $10 \%$ concentration of acrylamide in the resolving gel. Gels were stained with $0.2 \%$ Coomassie blue and were dried before autoradiography, which was carried out using Kodirex (Kodak) X-ray film. After electrophoresis and staining, the non-denaturing polyacrylamide tube gels were snap-frozen in liquid $\mathrm{N}_{2}$ and then sliced into $1 \mathrm{~mm}$ fractions, using a Mickle gel slicer (Gomshall, Surrey). ${ }^{125}$ I counts were detected by an LKB Ultragamma counter.

SDS-polyacrylamide tube gels were used to analyse ${ }^{125}$ I-labelled AUP after it had been extracted from precipitin arcs in AACE experiments. The ${ }^{125} \mathrm{I}$-labelled AUP $(21000 \mathrm{ct} / \mathrm{sec})$ was added to $5 \mu \mathrm{l}$ of unlabelled carrier AUP and subjected to AACE. The resultant AUP precipitin arc was detected autoradiographically, cut out with a scalpel and boiled in standard SDS extraction buffer (Maizel, 1971; Marsden et al., 1976). The molten agarose-SDS-tracer 
mix was pipetted onto tube gels where it cooled and set before the upper reservoir buffer was added.

Immunological activity of ${ }^{125}$ I-labelled AUP. Radioiodinated AUP was diluted in $0.5 \mathrm{M}$ sodium phosphate buffer, $\mathrm{pH} 7.5$, containing $2 \%$ horse serum (Wellcome Type 5) to give a count rate of about 100000 c.p.m. $/ \mathrm{ml}$. Aliquots $(50 \mu \mathrm{l}, 5000$ c.p.m.) of this solution were added to $100 \mu \mathrm{l}$ aliquots of increasing dilutions of anti-AUP antiserum. After incubation for $48 \mathrm{~h}$ at room temperature, bound and free antigen were separated by the addition of goat anti-rabbit IgG coupled to Sepharose (Den Hollander \& Schuurs, 1971). The mixture was shaken at room temperature overnight, $3 \mathrm{ml}$ of $0.05 \mathrm{M}$-sodium phosphate buffer containing $2 \%$ horse serum were added and the suspension of Sepharose was centrifuged at $4000 \mathrm{~g}$ for $5 \mathrm{~min}$. After this the precipitated Sepharose was washed with two more cycles of buffer followed by centrifugation. The bound radioactivity was then measured in the precipitated and washed Sepharose fraction.

Protein determinations were carried out using the Folin reaction (Lowry, Rosebrough, Farr \& Randall, 1951). AACE was carried out as previously described (Sutcliffe et al., 1978) using $4 \%$ rabbit anti-AUP in the antibody gel bed.

\section{Results and Discussion}

\section{Reactions of identity}

As shown in Pl. 1 (Figs 1 and 2), reactions of identity were obtained when paired samples of amniotic fluid and uterine extract were subjected to two-dimensional AACE. At the point of junction of the two precipitin arcs there was no evidence of spur formation which would indicate reactions of immunological non-identity. The quantity of the samples applied was chosen simply to provide enough AUP to detect spur formation if significant immunological differences existed between the samples. When run in the absence of a second sample, all 3 sources of AUP gave unimodal AUP precipitin arcs of identical mobility. The antiserum used in these experiments was raised against AUP from amniotic fluid and the results indicate that AUP in amniotic fluid does not contain detectable antigenic determinants additional to those found on uterine AUP. When the same samples of amniotic fluid and uterine AUP were tested against an antiserum to uterine AUP, reactions of identity were observed (results not shown), indicating that uterine AUP does not exhibit detectable antigenic determinants additional to those on AUP in amniotic fluid.

\section{AUP quantitation and chromatography}

One-dimensional AACE using a $4 \%$ concentration of antiserum was used to measure the concentration of AUP, because a linear relationship was found between the quantity of AUP applied to the antibody gel and the area under the resulting antigen peaks (Text-fig. 1). All AUP concentrations were expressed in arbitrary units per ml. This refers to the concentration of AUP

Table 1. Recovery of alpha uterine protein (AUP) from antibody affinity column

\begin{tabular}{lccccc}
\hline Material & $\begin{array}{c}\text { Volume } \\
(\mathrm{ml})\end{array}$ & $\begin{array}{c}\text { Conc. AUP } \\
\left(\text { Units*/ml) }^{*}\right.\end{array}$ & $\begin{array}{c}\text { AUP } \\
\text { (Units) }\end{array}$ & $\begin{array}{c}\text { Protein } \\
(\mathrm{mg})\end{array}$ & $\begin{array}{c}\text { AUP/protein } \\
\text { (Units/mg) }\end{array}$ \\
\hline Applied to column & 1.5 & 58.8 & 88.2 & 21.9 & 4.03 \\
Not retained by column & 93 & 0.59 & 54.5 & 13.7 & 4.00 \\
Retained before elution & - & - & 33.7 & 8.2 & 4.11 \\
Eluted in 2 M-KI, 50 mM-Tris & 186 & 0.07 & 13.0 & 7.07 & 1.84 \\
Percentage recovery & - & - & 38.6 & - & - \\
\hline
\end{tabular}

* See 'Materials and Methods' and Sutcliffe et al. (1978). 
found in a sample of amniotic fluid which was taken as a standard solution and arbitrarily defined as $1 \mathrm{unit} / \mathrm{ml}$. This method of quantitation was used to show that there was a $39 \%$ recovery of immunosorbed AUP when the antibody affinity column was eluted with $2.0 \mathrm{M}-\mathrm{KI}$, $50 \mathrm{~mm}$-Tris ( $\mathrm{pH} \mathrm{8.6)}$, as shown in Table 1. After dialysis, the eluted AUP was bound to a column of DEAE Sepharose from which it was then eluted at a mean salt concentration of 0.13 $\mathrm{M}-\mathrm{NaCl}$. Under these conditions serum albumin was eluted at a mean of $0.18 \mathrm{M}-\mathrm{NaCl}$. Subsequent gel filtration using Sephadex G-150 showed that AUP eluted from the column after haemoglobin and its molecular weight was estimated to be approximately 50000 (Text-figs 2 and 3).

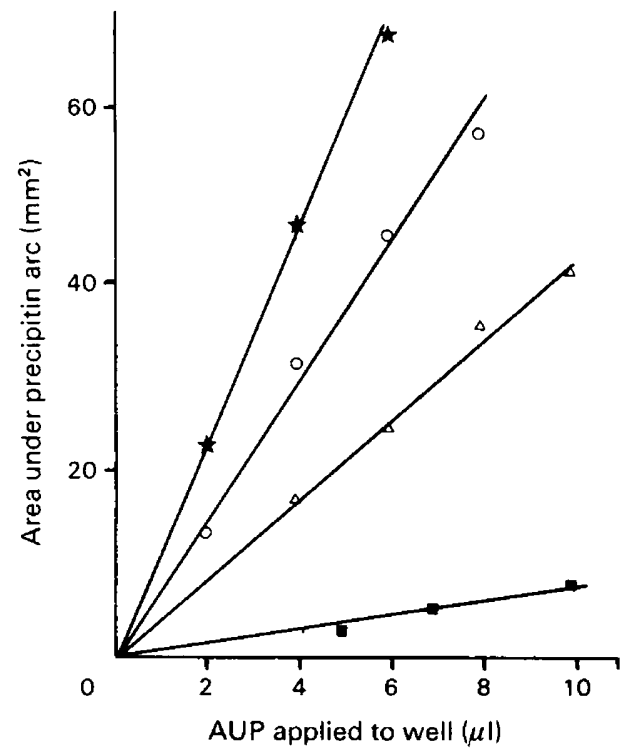

Text-fig. 1. The linearity of the AUP assay by one-dimensional AACE using $4 \%$ rabbit antiAUP. Two sources of AUP were used: decidua extracts in PBS $(\star, \square)$ and samples of two different second trimester amniotic fluids $(O, \Delta)$.

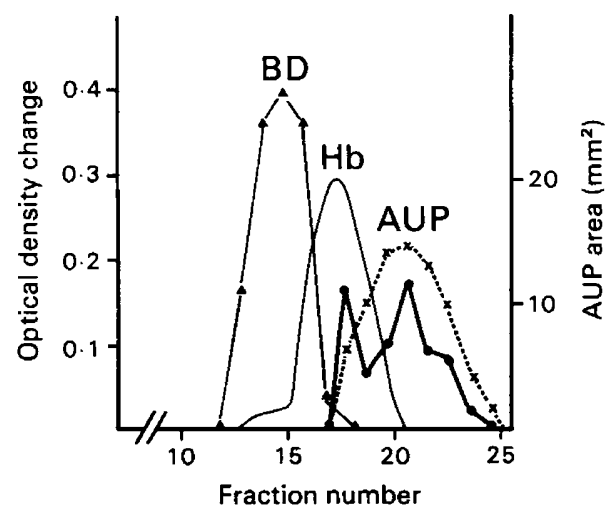

Text-fig. 2. Gel filtration of affinity-purified, ion exchange-fractionated AUP using a $0.9 \times 48$ $\mathrm{cm}$ Sephadex G-150 column (see 'Materials and Methods'). AUP was assayed by onedimensional AACE (---; see Text-fig. 1) and the total protein by the optical density at 280 $\mathrm{nm}(\mathrm{O})$. The results for blue dextran (BD; mol. wt $\left.=2 \times 10^{6}\right)$ and haemoglobin $\mathrm{A}(\mathrm{Hb})$ were obtained in parallel experiments. 


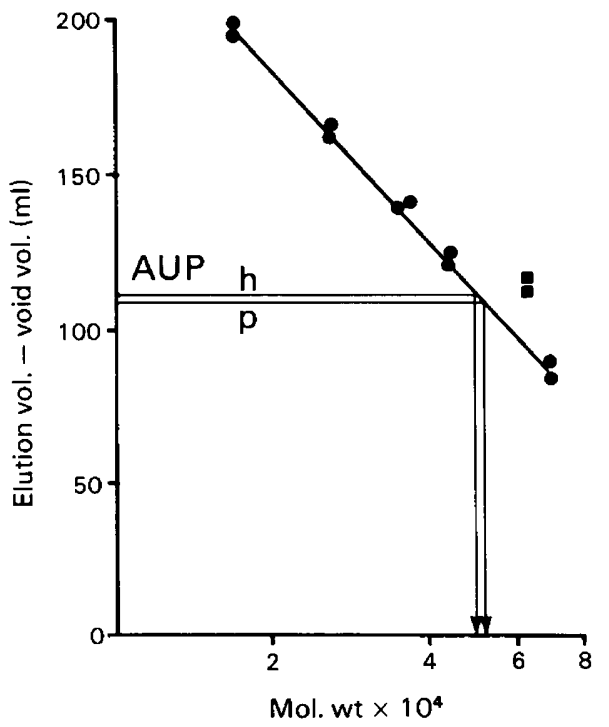

Text-fig. 3. Estimation of the molecular weight of AUP by G-150 chromatography. Samples of protein were fractionated and assayed by optical density at $280 \mathrm{~nm}$ (for standards) and AACE (for AUP). The void volume was subtracted from the elution volume of each protein and plotted against molecular weight semi-logarithmically. Samples: AUP h was AUP obtained from homogenates of decidua without prior purification: AUP $p$ had been partly purified by antibody affinity and ion-exchange chromatography. $\square$, Haemoglobin A.

\section{${ }^{125}$ Iodination and further analyses}

The ${ }^{125}$ I-labelled AUP was incorporated into a precipitin arc obtained by AACE (Pl. 1, Fig. 3 ) and the G-150 elution pattern of ${ }^{125}$ I-labelled AUP was similar to that of unlabelled AUP. Analysis of the unfractionated tracer by SDS-polyacrylamide gel electrophoresis (Text-fig. 4) showed that it contained a single major protein component with a mobility identical to that of the ${ }^{125} \mathrm{I}$-labelled protein recovered from the AUP precipitin arc shown in Pl. 1, Fig. 3. The molecular weight of this component was estimated in SDS slab gels to be between 23000 and 25000 (Text-fig. 5). The small quantity of material of larger molecular weight present in the unfractionated tracer could represent protein contaminants. However, the similarity between the major iodinated protein components in the unfractionated and in the immune precipitated AUP argues that the unfractionated protein is predominantly AUP. This conclusion is strengthened by the finding that $60-65 \%$ of the tracer could be immune precipitated using a specific anti-AUP antiserum (Text-fig. 6) and this percentage of immune precipitation was not inhibited by the addition of serum protein from adult men. Highly purified protein tracers (e.g. $\alpha$-fetoprotein, carcinoembryonic antigen) usually show a maximum immune precipitation of $55-90 \%$ (Bolton \& Glover, 1977), the residual non-precipitated counts being accounted for by the kinetics of the reaction and more especially by chemical and radiolytic denaturation of the protein as a consequence of radioiodination.

The molecular weight of AUP before fractionation and after final purification was determined by G-150 chromatography as approximately 50000 (Text-fig. 3), although this figure is an estimate since gel filtration is an empirical method of estimating molecular weights that takes no account of overall protein shape. However, it is clear that the molecular weight of the AUP polypeptide on SDS slab gel electrophoresis is less and lies in the region of 23000 25000 (Text-fig. 5). This indicates that AUP is a dimer which is composed of two similar or possibly identical polypeptide chains. 


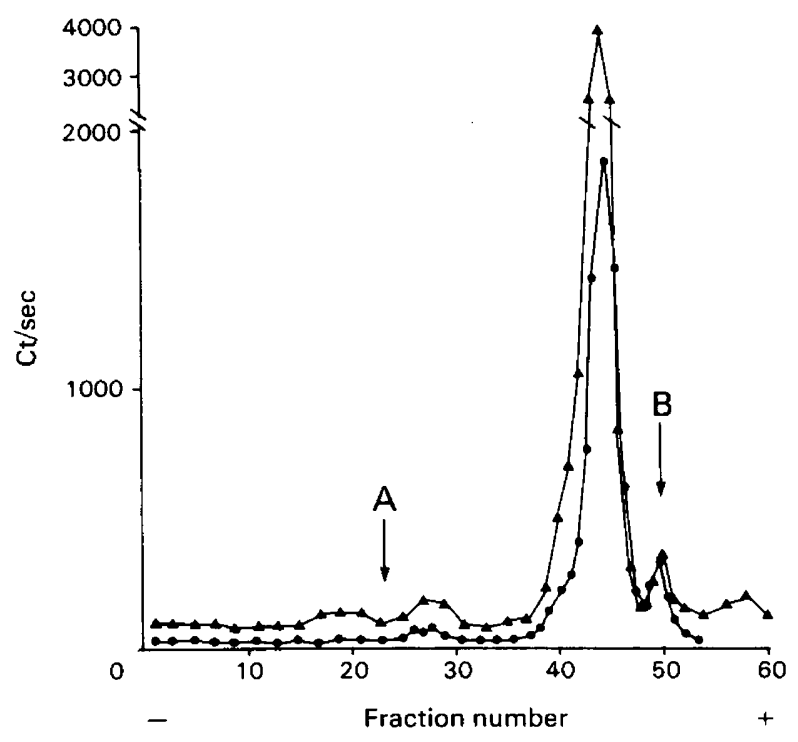

Text-fig. 4. SDS-5\% polyacrylamide tube gel electrophoresis of total ${ }^{125}$ I-labelled AUP tracer $(A)$ and tracer extracted from AACE precipitin arcs (O). Bromophenol blue (B) was included in each run. The mobility of albumin (A) was estimated from a parallel run of whole human serum containing total ${ }^{125}$ I-labelled AUP tracer. Correction has been made for differences in migration rate between the experiments (up to $12 \%$ as estimated from the bromophenol blue position).

There have been various reports of apparently uterine-specific proteins in rabbit and man (see Aitken, 1979, for review). Krishnan \& Daniel (1967) reported the presence of blastokinin in the rabbit uterus, at high concentration during the first week post coitum. This protein, which is also known as uteroglobin (Beier, 1968, 1974) and cone protein (Feigelson, 1976), was thought to induce cavitation in rabbit blastocysts in vitro (Krishnan \& Daniel, 1967). Although this conclusion has been disputed by Maurer \& Beier (1976), blastokinin may still have some indirect embryotrophic effect, perhaps associated with its postulated role as a progesterone carrier (Beier, 1976; Beato, 1977). Despite higher initial estimates by Krishan \& Daniel (1968), the molecular weight of blastokinin is now accepted to be approximately 15000 by gel filtration (Kay \& Feigelson, 1972; Daniel, 1976). It is not clear whether a blastokinin also exists in the human uterus. Daniel (1973) has provided evidence that material in human uterine extracts cross-reacts with rabbit blastokinin, although the nature of the cross-reacting material was not

\section{PLATE 1}

Figs 1 and 2. Tandem AACE to investigate the antigenic identity of AUP in amniotic fluid, decidua and endometrium. Samples of the antigens to be compared were placed in separate wells to the left-hand (cathodal) end of the first dimension gel. They were then subjected to electrophoresis from left to right. The mobility of albumin in the respective samples is indicated by the two circles at the bottom right of the figures. After this step, the antibody gel was added for the 2nd dimension electrophoresis. In Fig. 1, the antigens used were: left-hand (lower) well = 2nd trimester pooled amniotic fluid $(120 \mu \mathrm{g}$ protein in $20 \mu \mathrm{l})$, right-hand (upper) well = extract of decidua obtained from a termination of pregnancy at 11 weeks $(1.8 \mu \mathrm{g}$ protein in $5 \mu \mathrm{l})$. In Fig. 2, the antigens were: left-hand (lower) well = extract of premenopausal endometrium $(570 \mu \mathrm{g}$ protein in $10 \mu \mathrm{l})$, right-hand (upper) well = extract of decidua at 8 weeks of pregnancy $(12.64 \mu \mathrm{g}$ protein in $4 \mu \mathrm{l})$.

Fig. 3. An autoradiograph of ${ }^{125}$ I-labelled AUP (100 000 c.p.m. per well) in the presence of (left to right) $2 \mu \mathrm{l}, 4 \mu \mathrm{l}$ and $6 \mu \mathrm{l}$ amniotic fluid as a source of carrier AUP. In all three plates the antiserum was $4 \%$ rabbit anti-AUP. 


\section{PLATE 1}
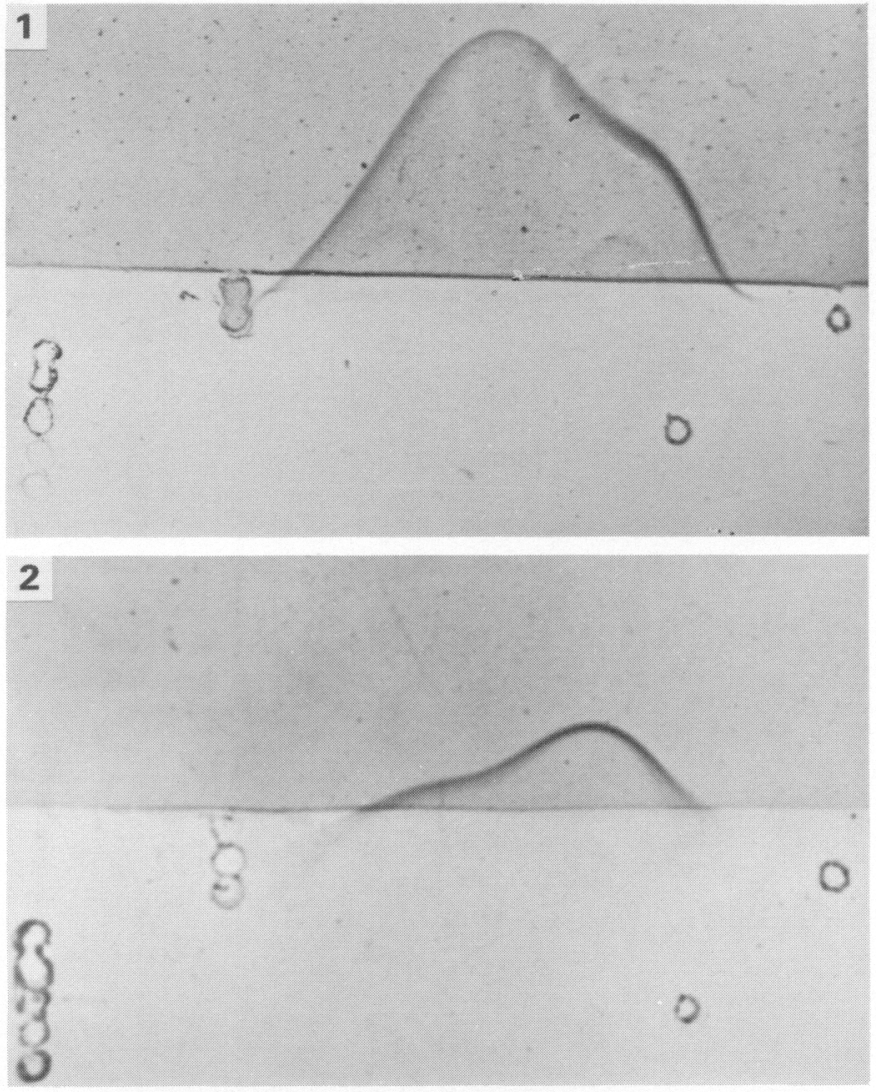

3

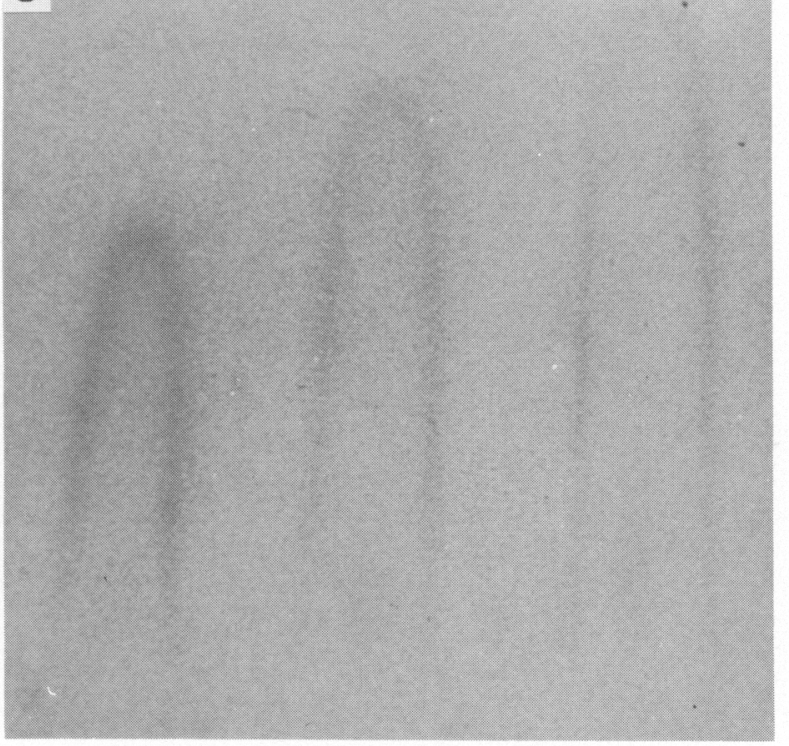

(Facing p. 440) 


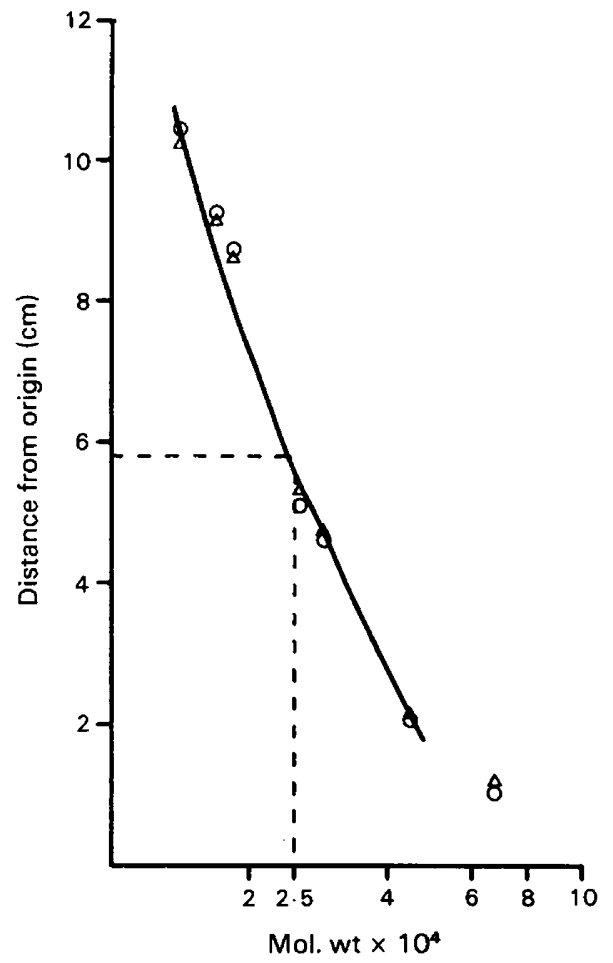

Text-fig. 5. Estimation of the molecular weight of ${ }^{125}$ I-labelled AUP by SDS-polyacrylamide slab gel electrophoresis. The mobility of AUP (_- _- ) is compared with a standard curve. The standards are those listed in 'Materials and Methods', plus $\alpha$-lactalbumin (mol. wt 14 076), human carbonic anhydrase B (29 000) and $\beta$-lactoglobulin subunit (18 400).

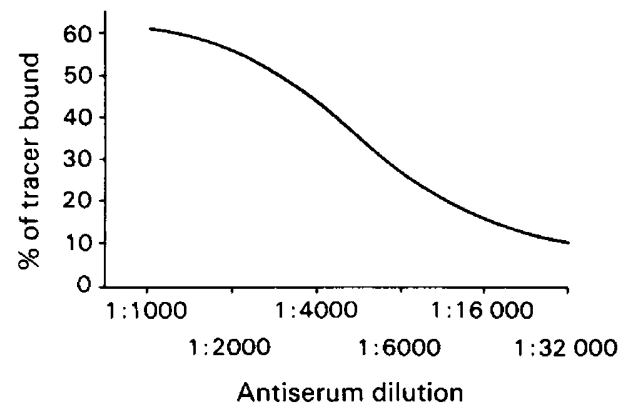

Text-fig. 6. Antiserum dilution curve, showing the proportion of ${ }^{125}$ I-labelled AUP tracer precipitated by rabbit anti-AUP.

characterized and the findings were not supported by Maathuis \& Aitken (1978). Roberts, Parker \& Henderson (1976) compared the proteins of uterine washes obtained at various stages of the menstrual cycle with serum protein patterns by polyacrylamide gel electrophoresis. They noted the lack of any major uterine protein of post-albumin mobility similar to that of blastokinin and concluded that blastokinin was not a major component of their material. Roberts et al. (1976) also observed some additional proteins in their extracts of uterine material; these were not detectable in serum and their tissue-specificity was not resolved.

The difference between the molecular weights of human AUP and rabbit blastokinin argues against a close homology between these two proteins. However, tests of immunological cross- 
reactivity await the raising of antisera against AUP in a species of animal other than rabbit (work in progress). Previous studies showed that the concentration of AUP in human amniotic fluid was high between 13 and 20 weeks of pregnancy (Sutcliffe et al., 1978). It is not known whether the concentration is even higher during the first trimester, as material is hard to obtain at this time and the interpretation of results is complicated by the presence of the extra-embryonic coelom (Hamilton \& Mossman, 1972). Whatever the cause of these high levels early in pregnancy, the results suggest that AUP is of biological significance at an early stage of gestation.

This work was supported by grants to R.G.S. from the M.R.C. and the Radiochemical Centre, Amersham.

\section{References}

Aitken, R.J. (1979) Uterine proteins. In Oxford Reviews of Reproductive Biology, Vol. 1 (in press). Ed. C. A. Finn. Oxford University Press, Oxford.

Beato, M. (1977) Hormonal control of uteroglobin biosynthesis. In Development in Mammals, Vol. 1, pp. 361-384. Ed. M. H. Johnson. North Holland, Amsterdam.

Beier, H. M. (1968) Uteroglobin: a hormone-sensitive endometrial protein involved in blastocyst development. Biochim. Biophys. Acta 160, 289-291.

Beier, H.H. (1974) Oviducal and uterine fluids. $J$. Reprod. Fert. 37, 221-237.

Beier, H.M. (1976) Uteroglobin and related biochemical changes in the reproductive tract during early pregnancy in the rabbit. J. Reprod. Fert., Suppl. 25, $53-69$.

Bolton, A.E. \& Glover, J.S. (1977) Radioiodination Techniques. Review No. 18. The Radiochemical Centre, Amersham, U.K.

Daniel, J.C., Jr (1973) A blastokinin-like component from the human uterus. Fert. Steril. 24, 326-328.

Daniel, J.C., Jr (1976) Temporal relationships between six uterine proteins associated with early pregnancy in the rabbit. Protides Biol. Fluids 24, 133-137.

Den Hollander, F.C. \& Schuurs, A.H.W.M. (1971) The assay of polypeptide hormones In Radioimmunoassay Methods, pp. 419-422. Eds K. E. Kirkham \& W. M. Hunter. Churchill, Edinburgh.

Feigelson, M. (1976) Reproductive tract fluid proteins. Protides Biol. Fluids 24, 143-146.

Hamilton, W.J. \& Mossman, H.W. (1972) Human Embryology. Heffer, Cambridge.

Hunter, W.H. \& Greenwood, F.C. (1962) Preparation of Iodine-131 labelled human growth hormone of high specific activity. Nature, Lond. 194, 495-496.
Kay, E. \& Feigelson, M. (1972) An estrogen modulated protein in rabbit oviducal fluid. Biochim. Biophys. Acta 271, 436-441.

Krishnan, R.S. \& Daniel, J.C., Jr (1967) 'Blastokinin': Inducer and regulator of blastocyst development in the rabbit uterus. Science, N.Y. 158, 490-492.

Krishnan, R.S. \& Daniel, J.C., Jr (1968) Composition of 'blastokinin' from rabbit uterus. Biochim. Biophys. Acta 168, 579-582.

Lowry, O.H., Rosebrough, N.J., Farr, A.L. \& Randall, R.J. (1951) Protein measurement with the Folin phenol reagent. J. biol. Chem. 193, 265-275.

Maathuis, J.B. \& Aitken, R.J. (1978) Protein patterns of human uterine flushings collected at various stages of the menstrual cycle. J. Reprod. Fert. 53, 343-348.

Maizel, J.V. (1971) Polyacrylamide gel electrophoresis for viral proteins. In Methods in Virology Vol. V, pp. 179-246. Eds K. Maramorosch \& H. Koprowski. Academic Press, New York.

Marsden, H.S., Crombie, I.K. \& Subak-Sharpe, J.H. (1976) Control of protein synthesis in Herpes virusinfected cells. J. gen. Virol. 31, 347-372.

Maurer, R.R. \& Beier, H.M. (1976) Uterine proteins and development in vitro of rabbit preimplantation embryos. J. Reprod. Fert. 48, 33-41.

Pihko, H., Lindgreen, J. \& Ruoslahti, E. (1973) Rabbit $\alpha$ fetoprotein: immunochemical purification and partial characterisation. Immunochemistry 10, 381-385.

Porath, J., Axén, R. \& Ernback, S. (1967) Chemical coupling of proteins to agarose. Nature, Lond. 215, 1491-1492.

Roberts, G.P., Parker, J.M. \& Henderson, S.R. (1976) Proteins in human uterine fluid. J. Reprod. Fert. 48, 153-157.

Sutcliffe, R.G., Brock, D.J.H., Nicholson, L.V.B. \& Dunn, E. (1978) Fetal- and uterine-specific antigens in human amniotic fluid. J. Reprod. Fert. 54, 85-90.

Received 9 August 1979 